\title{
Test Types, Students' Achievement in Senior Secondary School Physics and Eradication of Poverty and Hunger In Nigeria
}

\author{
UduakU.Effiong $^{1}$, NkwoI.Nkwo ${ }^{1}$, Nsungo N. Udo ${ }^{2}$ \\ ${ }^{I}$ Department of Curriculum \& Instructional Technology, Faculty of Education, Cross River University of \\ Technology, Calabar, Nigeria \\ ${ }^{2}$ Department of Physics, Cross River State College of Education, Akamkpa, Nigeria
}

\begin{abstract}
The study examined the effect of test type on students' achievement in senior secondary school physics. The main thrust of the study was to test the hypothesis that there is no significant difference in achievement in physics among senior secondary school students (male and female) tested on the Extended Essay, Restricted Essay, and Multiple-choice test types. The sample consisted of 102 senior secondary two (SS II) physics students in three randomly selected secondary schools in Akamkpa Urban of Cross River State, Nigeria. The subjects were used in their intact class settings in the three schools. Treatment consisted of presentation of six structured physics lessons of 45 minutes duration per lesson to each intact class for three weeks. Each intact class was exposed to treatment for 270 minutes with lessons on modern physics delivered by one of the researchers to control for extraneous teacher-related factors. The Modern Physics Achievement Test (MPAT), developed by the researchers, was used to obtain pre-test and post-test scores. The pre-test data confirmed homogeneity of the groups. The post-test data were analyzed using the $3 \times 2$ factorial analysis of variance. The study showed that students significantly achieved better in Multiple-choice test type than in the Restricted essay and the Extended essay test types, irrespective of gender. It was therefore recommended that test packages should in all cases include all forms of test types, especially essay test types for effective evaluation of students' achievement in physics. Such action would ensure quality science education for the eradication of poverty and hunger.

Keywords: Achievement, Hunger, Physics, Poverty, Test
\end{abstract}

\section{Introduction}

On the $6^{\text {th }}$ of September, 2000, 189 Heads of States and Government held a summit at the United Nations Headquarters, New York, United States of America, where they examined the need to tackle world poverty in all its ramifications. The leaders were concerned with how the entire human race, distributed across the globe, could benefit from development. Against this background, the summit resolved on achieving specific goals in 2015 in order to ensure that development will be evident everywhere to everyone. These specific goals are commonly called the "Millennium Development Goals" (MDGs).

Eight MDGs were adopted by the world leaders, with twenty-one indicators for performance assessment. The eight MDGs are:

i. Eradicate extreme poverty and hunger

ii. Achieve universal primary education

iii. Promote gender equality and empower women

iv. Reduce child mortality

v. Improve maternal health

vi. Combat HIV/AIDS, malaria and other diseases

vii. Ensure environmental sustainability

viii. Develop a global partnership for development.

In Nigeria, there has been commitment by Government towards realizing these goals. This is evident in the appointment of a Special Adviser to the President of Nigeria on MDGs. Unfortunately, because of lack of clear statistics, the extent of achievement of these goals is hardly discernable.

To compound this helplessness, is the stark reality of poverty and hunger, low enrolment in primary schools, high maternal and child mortality rate, and increasing rate in the spread of HIV/AIDS. To this extent, many wonder whether the achievement of the MDGs is feasible within the target date of 2015. There is the possibility of approaching the attainment of these goals in 2015 and shortly beyond, if the proper strategies are adopted. Otherwise, the MDGs will exist as mirage in developing nations.

The National Policy on Education states aptly that "Education in Nigeria is an instrument "par excellence' for effecting national development"[1]. This implies, unequivocally, that with quality education, 
accessible and affordable, development (as defined within the context of the MDGs) can be realized everywhere in Nigeria in the set time, or shortly beyond.

This leaves us with much to ponder upon. What is the state of our education sector and programme? Do we have education programme that can develop the proper mindset of its citizens such that they can have ideas that could transform their society? The truth is, our education programme, the supposed instrument 'par excellence', needs to be re-packaged to deliver on the development targets. Our query here is on the 'quality of education'. To this extent, B. O.Nnaji decried the quality of our school system thus:

"The quality of our graduates today leaves much to be desired. We have graduates who hardly make sense when they speak, can barely craft two correct sentences in a page-long essay; are experts in plagiarized theses based on simulated data because they hardly appreciate the value of rigorous research...The decay, however, did not start from the Universities. At the lower school levels, primary and secondary schools, we have continued to witness a debilitating decline in educational standards..."[2]

P. Obanya identified essential input elements of quality in education to include the curriculum, the teaching force, the infrastructure, materials, among others[3]. Indeed, the quality of education must begin with the input elements to guarantee quality outcomes. The poor performance of our students cannot be divorced from poor quality of instruction (teaching) in the classrooms.

The teaching process consists of the delivery of instruction and the evaluation of learning. In most cases, the delivery of instruction is below standard, and the evaluation process leaves much to be desired. These days, as observed by B. O. Nnaji, our students cannot write good essays and speak good English[2]. This may not be unconnected with the way we carry out evaluation of learning in our school system, where emphasis is placed on the use of multiple-choice test type largely because of the relative ease of grading of the scripts.

A test is an instrument designed for objective and quantifiable sampling of behaviour of a person[4], [5], [6], [7]. In schools where our focus is on determining the degree of learning that has taken place after series of delivery of instruction, the test under reference is the achievement test.

M. T. Joshua and A. Ali defined achievement test as a testing instrument that measures what an individual has learnt from a teaching session(s)[7], [8]. There are basically two types of achievement tests: the essay type and the objective type[9], [7]. When candidates are required to write elaborately and constructively in response to a test item, such test is called Extended Essay test. However, when candidates are required to supply specific short answers (sometimes a word, or words, or a sentence) to a test item, the test is called the Restricted Essay test. When candidates are required to simply choose the correct option among given alternatives in response to a test item, such test is the Multiple-choice test. Experts have argued that each of these test types is useful to the extent that the test is reliable and valid[6],[7].

The examination bodies in Nigeria, namely, the West African Examination Council (WAEC) and National Examination Council (NECO) adopt a combination of the extended essay, restricted essay (or shortanswer essay), and the multiple-choice test types for the assessment of students at the secondary school certificate examinations. Notwithstanding, the weighting of the marks obtainable is in favour of the multiplechoice sections.

However, the Joint Admission and Matriculation Board adopts the multiple- choice test type only to prepare the Unified Tertiary Matriculation Examination (UTME). The problem here is that all the weaknesses associated with multiple- choice tests affect the standard of the outcomes/scores earned by the candidates in this placement/selection examination.

In other words, we could have candidates who could score highly in JAMB UTME but cannot write good essays and yet gain admission into the University in Nigeria. And in a situation where the Universities cannot maintain strict quality controls, such candidates sneak through the ivory tower emerging as "graduates" bereft of functional skills and intellectual prowess. And the problem of poor quality of our educational system lingers on as these graduates, in most cases, remain unemployable, poor and hungry, and cannot raise a healthy family. The root cause of this condition, certainly, is the assessment strategy which gave advantage to candidates to gain admission into the university. To this extent therefore, to rely wholly on multiple-choice test for the assessment of students' academic achievement may end in disaster.

To enable us verify this assertion, this study attempted to determine the effect of test types on students' achievement in physics among senior secondary school students in Cross River State. The choice of physics may not be unconnected with the fact that it is one subject that determines, to a large extent, the prospects of many students making careers in science and technology in Universities. Therefore, if we must make progress in science and technology, and eradicate poverty and hunger through proper development of technological products, then the teaching and learning of physics in our school system must be given priority attention. 
The purpose of the study was:

\section{Purpose of the study}

i. To determine if there is any significant difference in achievement in physics among senior secondary school students tested on Extended essay, Restricted essay (or short-answer essay) and multiple-choice test types.

ii. To determine if there exists any significant difference in achievement between male and female physics students tested on Extended essay, Restricted essay (or short-answer essay) and multiple-choice test types.

iii. To determine if there is any interaction effect of test types and gender on students' achievement in physics.

\section{Statement of hypotheses}

The following hypotheses were formulated to guide the study:

i. There is no significant difference in achievement in physics among senior secondary school students tested on Extended essay, Restricted essay (or short-answer essay) and multiple-choice test types.

ii. There is no significant difference in achievement in physics between male and female students tested on Extended essay, Restricted essay (or short-answer essay) and multiple-choice test types.

iii. There is no significant interaction effect of test type and gender on students' achievement in senior secondary school physics.

\section{Research method}

The study adopted the quasi-experimental pretest-posttest design. The study population consisted of 308 Senior Secondary Two (SS II) physics students in sixteen public secondary schools in Akamkpa LGA of Cross River State. From the sixteen secondary schools, all of which satisfied basic infrastructure requirements, three schools were randomly selected, using the hat-and-draw sampling technique. Therefore, the sample consisted of 102 physics students in the three selected schools. The subjects were used in intact classes for the experiment.

Treatment consisted of teaching structured lesson of 45 minutes duration to the students in their intact classes, two times a week, for three weeks. One of the researchers carried out the teaching to control for teacher effects across the three schools and classes. Hence, the subjects in each school received 270 minutes of instruction in modern physics, for the three weeks, after which they were assessed.

The assessment instrument was the Modern Physics Achievement Test (MPAT) developed by the researchers. The instrument had three forms, namely, MPAT I (Extended Essay version), MPAT II (Restricted Essay version) and MPAT III (Multiple-Choice version). The instrument was adjudged valid by experts in science education, and measurement and evaluation. To establish the reliability of the MPAT I, II, and III, the instrument was administered to three different samples of comparable levels and re-tested after two weeks. The Kuder-Richardson - 21 indices for the instrument were MPAT I (0.65); MPAT II (0.75); MPAT III (0.79). The items in MPAT were mostly drawn from past WASCE and NECO examinations in physics.

The MPAT was administered to the subjects as pre-test before the commencement of treatment. Analysis of the pre-test outcomes showed that the three groups were homogeneous. After treatment, the subjects were administered the MPAT, one form for each school (represented by an intact class). Hence, three groups emerged. No school/class was examined using more than one version of MPAT.

\section{Results}

The data were analyzed using the 2-way analysis of variance and the results are indicated in table I below. All hypotheses were tested at 0.05 level of significance.

Table I: 3 x 2 Factorial analysis of variance of MPAT scores of SS II students distributed by test types and gender.

\begin{tabular}{|lccccc|}
\hline Sources of Variation & SS & df & MS & F & $\begin{array}{c}\text { Decision at } \\
\mathbf{p}<.05\end{array}$ \\
\hline Main effect & 664.43 & 3 & 148.19 & 6.97 & $*$ \\
Test types & 1032.19 & 2 & 516.95 & 24.32 & $*$ \\
Gender & 367.76 & 1 & 367.76 & 17.29 & $*$ \\
Interaction & 435.91 & 2 & 217.96 & 10.25 & $*$ \\
Within & 2126.40 & 100 & 21.26 & & \\
Total & $\mathbf{3 2 2 6 . 7 5}$ & $\mathbf{1 0 1}$ & & & \\
\hline
\end{tabular}


* Significant at $\mathrm{p}<0.05$

From Table I, the calculated F-values for test types (24.32), gender (17.29), and main effect (6.97) were greater than the critical F-values, suggesting a rejection of the respective null hypotheses. Similarly, table I shows that the calculated F-value of interaction effect of test type and gender (10.25) is greater than the critical F-value of 3.09 , suggesting a rejection of the null hypothesis.

The Scheffe's post-hoc multiple comparison test analysis was performed on the group means to determine the directions of the significant results. The post-hoc analysis shows that:

i. The Multiple-choice testees scored significantly higher than the Restricted Essay and Extended Essay testees.

ii. The male students achieved significantly higher than the female students, across test types.

\section{Discussion}

The study showed that students' overall performance in science is affected by the type of tests used for examination. Specifically, the Multiple-choice test type showed a picture of higher performance than the Essay test types. This result is in agreement with the observation by B. O. Nnaji that our students can no longer write essays[2]. The essay test type fosters originality, selection, organization and integration of ideas ([6], [7]) of which most of our students are bankrupt. Furthermore, essay test type demands good writing skills of logical presentations and legibility[7]. In this era of cell phone text messages, the skill of writing is fast disappearing among our youths. Can we confidently say that most of our students have the capacity for analytical and logical reasoning which is critical for generation of ideas?

Yet our placement/selection examinations (e.g. JAMB UTME) adopt a testing measure (the multiplechoice test) that has the tendency of showing generally good performance in any given subject. On their part, the WAEC and NECO weight the multiple-choice test section more than the Essay test sections, thereby obscuring the literacy handicap of our youths in the overall performance.

If we sincerely want to eradicate poverty and hunger, there is need to improve on the quality of our science education programme. B. O. Nnaji summarized this view point succinctly:

"We must understand that technology leads to products, products lead to companies, and companies employ people. When people are employed you have prosperity because it is the prosperity that makes it possible for people to have money to spend ..."[2]

Indeed, when people have money to spend, they will be able to feed well; give their children good education (irrespective of gender); provide adequate care for their wives during and after pregnancy, thereby reducing maternal and child mortality, maintain respectable social life styles, which reduces the chances of contracting sexually transmitted infections (STIs); provide care to those in need; develop and maintain serene environment and engage in global partnership for sustainable development. Hence, the key to achieving the MDGs in 2015 or shortly beyond is implementation of quality education, nay science education, in all its ramifications.

Data obtained also showed that male students achieved significantly higher than the female students, across test types. Cultural prejudices against women education in the sciences (particularly physics) could likely account for this significant male superiority over female students in physics achievement[10]. However, adopting best practices in classroom instruction delivery can, over some period, minimize this gender inequality against females.

\section{Conclusion}

From the data obtained in this study, we conclude that the students' achievement is dependent on the type of test administered to them, among other factors. Particularly, data showed that the tendency to guess, and guess correctly, obtain assistance during examinations, among other weaknesses, makes it possible for multiple-choice test type to greatly influence students' achievement more than the Essay test types.

\section{Recommendations}

To ensure quality in our education programme, which will lead to the eradication of poverty and hunger, we recommend as follows:

i. The present weighting of the different test types in our examination systems should be reviewed, placing higher priority on Essay test type and least priority on multiple-choice test type. A of 60:40 ratio is recommended in favour of essay test type, in order to encourage thinking and writing skills among our youth.

ii. Qualifying/selection examinations should not be limited to multiple-choice test type. Efforts should be made to develop essay test components to give us a balanced assessment of the intellectual ability of our youths. 


\section{REFERENCES}

[1] Federal Republic of Nigeria, National Policy on Education(Lagos: NERDC, 2004).

[2] B. O. Nnaji,Technology for Human Advancement: Prospects and challenges in the $21^{\text {st }}$ century, $1^{\text {st }}$ Convocation Lecture of Cross River University of Technology, Calabar, $21^{\text {st }}$ May, 2010, 25 - 26.

[3] P.Obanya, Revitalizing Education in Africa (Ibadan: Stirling-HordenPublishers, 2002).

[4] D. I. Denga, Educational Measurement, Continuous Assessment and Psychological testing(Calabar: Rapid Educational Publishers, 1986).

[5] A. O. Udoh and E. U. Joseph,Foundations of Educational Research(Uyo: JoeGraph Publications, 1999).

[6] U. D.Ndem, A. O.Udoh, and E. U.Joseph, Tests and Measurement for Teachers and Students(Uyo: Dorand Publishers, 2000).

[7] M. T.Joshua, Fundamentals of tests and measurement in Education(Calabar: The University of Calabar Press, 2005).

[8] A. Ali, Conducting research in education and the social sciences (Enugu: Tashiwa Networks Ltd, 2006).

[9] G. Sax, Principles of Educational Measurement and Evaluation (Belmong: Woodswork Publishing Co. Inc., 1976).

[10] P. Okebukola, Beyond the stereotype to new trajectories in science teaching, Special Lecture, $43^{\text {rd }}$ Annual Conference of Science Teachers Association of Nigeria (STAN), $19^{\text {th }}-23^{\text {rd }}$ August, 2002). 